\title{
MUSCULOSKELETAL ULTRASOUND AND ITS APPLICATION IN SPORTS MEDICINE
}

\author{
A ULTRASSONOGRAFIA MUSCULOESQUELÉTICA ESUA APLICAÇÃONA MEDICINA DO ESPORTE
}

N TRRC

Original Article

Artigo Original

Artículo Original

\section{EL ULTRASONIDO MUSCULOESQUELÉTICO YSU APLICACIÓN EN LA MEDICINA DEL DEPORTE}

\begin{abstract}
Introduction: Musculoskeletal ultrasound is a clinical auxiliary examination for the diagnosis of musculoskeletal system injuries by ultrasound imaging technology. Objective: To explore the real time application value of musculoskeletal ultrasound in exercise. Methods: The MSKUS technique was used to diagnose and classify the types, positions and degrees of sports injuries. Results: A total of 35 athletes received a MSKUS diagnosis; 2 athletes were recommended to withdraw from competition after the diagnosis and return to China for treatment. Among the athletes, 9 cases (25.71\%) suffered muscle injury, 22 (62.86\%) suffered tendon, ligament and fascia injury, 2 (5.71\%) suffered bone and cartilage injury, and 2 (5.71\%) suffered bursitis. The main site of injury was the lower extremity (74.29\%). Most of the injuries were mild, and only 2 cases were severe. Conclusions: Musculoskeletal ultrasound has certain advantages in the real-time diagnosis of tendons, ligaments and soft tissue in the field. Using musculoskeletal ultrasounds, doctors can assess the injury situation more quickly and accurately, and choose the next steps concerning exercise prescription and a rehabilitation treatment plan more effectively. Musculoskeletal ultrasound is real time, reliable and convenient, and has application value in sports. Level of evidence ll; Therapeutic studies - investigation of treatment results.
\end{abstract} (Physical Education Professional) Seung-Soo Baek (ID (Physician)

1. Department of Sport \& Health Science, College of Natural Science, Sangmyung University, Seoul, Republic of Korean.

\section{Correspondence}

Seung-Soo Baek

Seoul, 03016, Republic of Korean. bt202135@163.com

Keywords: Musculoskeletal and Neural Physiological Phenomena; Athletic Injuries; Diagnosis.

\section{RESUMO}

Introdução: Aultrassonografia musculoesqueléticaéum exame clínico auxiliar para o diagnóstico de lesões do sistema musculoesquelético através da tecnologia por imagens ultrassonográficas. Objetivo: Explorar ovalor de aplicação em tempo real da ultrassonografia musculoesquelético para exercícios. Métodos: A técnica USME foi utilizada para o diagnóstico e a classificação de tipos, posições e graus de lesão causadas pela prática do esporte. Resultados: Um total de 35 atletas receberam diagnósticos por USME; 2 atletas foram recomendados a se retirarem da competição após o diagnóstico e voltarem para a China para tratamento. Entreos atletas, 9 eram casos $(25,71 \%)$ de lesão muscular, $22(62,86 \%)$ eram casos de lesão de tendão, ligamento e fáscia, $2(5,71 \%)$ sofriam de lesões ósseas e de cartilagem, e 2 (5,71\%) sofriam de bursite. O local principal das lesões era a extremidade inferior (74,29\%). A maioria das lesões eram leves, e apenas dois casos eram graves. Conclusões: A ultrassonografia musculoesquelética apresenta certas vantagens no diagnostico em tempo real de tendões, ligamentos $e$ tecido mole na área. Com a ultrassonografia musculoesquelética, médicos podem avaliar a situação da lesão com maior rapidez e precisão, eescolher os próximos passos quanto a prescrição de exercícios e um plano de tratamento de reabilitação com maior eficácia. A ultrassonografia musculoesqueléticaéfeita em tempo real, é confiável e conveniente, e tem um valor de aplicação para os esportes. Nível de evidência ll; Estudos terapêuticos-investigação de resultados de tratamento.

Descritores: Fenômenos musculoesqueléticos eneurofisiológicos; Lesões em atletas; Diagnóstico.

\section{RESUMEN}

Introducción: El ultrasonido musculoesquelético es un examen clínico auxiliar para el diagnóstico delesiones del sistema musculoesquelético a través de la tecnología por imágenes ultrasonográficas. Objetivo: Explorar el valor de aplicación en tiempo real del ultrasonido musculoesquelético para ejercicios. Métodos: La técnica USME se utilizó para el diagnóstico y clasificación de tipos, posiciones y grados de lesión causadas por la práctica de deporte. Resultados: Un total de 35 atletas recibieron diagnósticos por USME; se recomendó a 2 atletas que se retiraran de la competición tras el diagnóstico y que volvieran a China para tratamiento. Entre los atletas, 9 (25,71\%) eran casos de lesión muscular, 22 (62,86\%) eran casos de lesión de tendón, ligamento y fascia, 2 (5,71\%) sufrían de lesiones óseas y de cartílago, y 2 (5,71\%) sufrían de bursitis. El sitio principal de lesiones era la extremidad inferior (74,29\%). La mayoría de las lesiones eran leves, y solo dos casos eran graves. Conclusiones: El ultrasonido musculoesquelético presenta ciertas ventajas en el diagnóstico en tiempo real de tendones, ligamentos y tejido blanco en el área. Con el ultrasonido musculoesquelético, médicos pueden evaluar la situación de la lesión con mayor rapidez y precisión, y elegir los próximos pasos cuanto a la prescripción de ejercicios y un plan de tratamiento de rehabilitación con mayor eficacia. El ultrasonido musculoesquelético se hace en tiempo real, es confiable y conveniente, y tiene un valor de aplicación para los deportes. Nivel de evidencia ll; Estudios terapéuticos - investigación de resultados de tratamiento.

Descriptores: Fenómenos musculoesqueléticos y neurofisiológicos; Lesiones en atletas; Diagnóstico. 


\section{INTRODUCTION}

Musculoskeletal ultrasound (musculoskeletalultrasound, MSKUS) is a recently developed in our country's emerging medical ultrasound technology, it will be the traditional medical ultrasonic application in muscle and nerve and bone related diseases diagnosis and treatment, therefore, it fills the gap in the diagnosis of nerve, muscle and joint diseases by ultrasound. ${ }^{1}$ Since the use of ultrasound in the last century to identify popliteal cysts and venous thrombosis, and especially with the use of high-frequency linear array probes, resolution has improved dramaticall, MSKUS can clearly distinguish nerves, tendons, synovium and other tissues. MSKUS can also clearly display the bone cortex, hyaluronic cartilage, synovial tissue with regular shape and linear high-echo joint capsule and other structures. The examiner can ask the patient to dynamically observe the lesion site by active and passive activities. Compared with other imaging examinations commonly used in sports medicine, such as X-ray, CT, MRI (nuclear magnetic resonance imaging), musculoskeletal ultrasound has many advantages such as non-invasive, non-radiation, no absolute contraindications, low cost, convenient operation, etc., and can also dynamically observe the movement of muscles and tendons, which can be complementary with CT and MRI, providing a different perspective for clinical diagnosis of nerve and muscle diseases. ${ }^{2,3}$ Therefore, through the comparative observation and analysis of the diagnosis of sports injury in marathon by musculoskeletal sonographer and sports medicine physician, the sports injury was analyzed, the athletes' recovery was followed up, and the real-time application value of musculoskeletal ultrasound in sports was analyzed, so as to provide reference for the application in future competitions. ${ }^{4}$

\section{METHOD}

\section{Subjects}

In this study, 35 Chinese elite athletes diagnosed by MSKUS during a sports meeting were selected as the research objects, including 21 males and 14 females, aged $23.91 \pm 2.06$ years old.

\section{Instruments and research methods}

The practical operation was completed by the attending physician of Functional Testing Department of General Administration of Sport of China and guided by Doctor of Sports Medicine of Indiana University, USA. The Hitachi Noblus color Doppler portable diagnostic instrument is used, and the linear array probe is L55 (frequency is $5 \sim 13 \mathrm{MHz}$ ). During the examination, athletes should be instructed to keep comfortable posture and fully expose the injured part according to the injured part. The lesion site was explored in multiple sections, the healthy side and the affected side were contrastive explored and dynamic explored. To fully understand the extent of injury, tissue integrity, internal echo, surrounding soft tissue, blood vessels, nerves and other conditions.

\section{Observation Indicators}

The ultrasonic manifestations of different types and degrees of injury were different. Diagnostic criteria for muscle injury: 1) Mild injury: the texture of muscle fiber is blurred, and the texture direction and continuity of muscle fiber are normal/no abnormal; 2) Moderate injury: muscle fiber texture disorder, uneven internal echo, partial fiber texture continuity interruption or muscle tearing completely. According to the mechanism of injury and the occurrence of symptoms, injury was divided into acute injury and chronic injury. Acute injury was sudden injury with clear cause and symptoms; Chronic injuries are injuries that result from overuse.

\section{Statistical analysis}

The number of cases and percentage were used for data processing. Chi-square test was used for comparison between groups, and $\mathrm{P}<0.05$ was considered statistically significant.

\section{RESULTS}

During the Games, MSKUS received 35 athletes in 22 sports, including basketball, badminton, swimming, wrestling, gymnastics, taekwondo, hockey, cycling, three-man basketball, sailing and so on. Among them, 33 athletes received immediate treatment after being diagnosed with MSKUS and successfully completed the race without any aggravation of their injuries. One female gymnast suffered a partial tear of the medial collateral ligament of the right knee joint. The left supraspinatus tendon was completely ruptured and the left acromioclavicular joint was dislocated. After ultrasound experts and surgical experts jointly decided that the two athletes should withdraw from the competition and return to China for surgical treatment. Among the injury types, tendons, ligaments and fascia were the main injuries, accounting for $62.86 \%$, and the incidence was significantly higher than other injury types, $P<0.05$. (Table 1) Among the acute and chronic injuries, the incidence of chronic injuries was significantly higher than that of the acute injury group, accounting for $74.29 \%, P<0.05$. (Table 2)

Most of the injury sites were concentrated in the lower extremities, mainly the knee joint and ankle joint, and there was no significant difference in the incidence of various injury types. (Table 3)

In terms of the use of ultrasound, the Department of Ultrasound did not receive any athletes 4 days before the start of the competition, and the number of athletes received gradually increased from the 5th day, the number of athletes treated by ultrasound reached a peak on the 10th day of the competition, and thereafter the number of athletes treated gradually decreased. (Figure 1)

\section{DISCUSSION}

\section{Early diagnosis and early warning of minor injuries}

In this study, there were 7 athletes with acute mild injuries, including mild muscle strain, minor phalanx fracture, and acute bursitis. After the

Table 1. Types and proportions of injuries diagnosed by MSKUS in athletes.

\begin{tabular}{c|c|c|c|c|c}
\hline & $\begin{array}{c}\text { The number } \\
\text { of cases }\end{array}$ & $\begin{array}{c}\text { Slightly } \\
\text { damaged }\end{array}$ & $\begin{array}{c}\text { Moderate } \\
\text { damage }\end{array}$ & $\begin{array}{c}\text { Severe } \\
\text { damage }\end{array}$ & $\%$ \\
\hline Muscle damage & 9 & 9 & 0 & 0 & 25.71 \\
\hline $\begin{array}{c}\text { Injuries to tendons, } \\
\text { ligaments and fascia }\end{array}$ & 22 & 20 & 0 & 2 & $62.86^{*}$ \\
\hline $\begin{array}{c}\text { Bone and cartilage } \\
\text { damage }\end{array}$ & 2 & 2 & 0 & 0 & 5.71 \\
\hline $\begin{array}{c}\text { Slippery bursa } \\
\text { phlogistic }\end{array}$ & 2 & 0 & 0 & 0 & 5.71 \\
\hline
\end{tabular}

Note: ${ }^{*}, P<0.05$, the same as below. Percentage data is rounded to $99.99 \%$, resulting in a final sum.

Table 2. Ratio of acute and chronic sports injuries diagnosed by MSKUS

\begin{tabular}{c|c|c|c|c|c}
\hline & $\begin{array}{c}\text { The number } \\
\text { of cases }\end{array}$ & $\begin{array}{c}\text { Slightly } \\
\text { damaged }\end{array}$ & $\begin{array}{c}\text { Moderate } \\
\text { damage }\end{array}$ & $\begin{array}{c}\text { Severe } \\
\text { damage }\end{array}$ & $\%$ \\
\hline Acute injuries & 9 & 7 & 0 & 2 & 25.71 \\
\hline Chronic injury & 26 & 26 & 0 & 0 & $74.29^{*}$ \\
\hline
\end{tabular}

Table 3. Ratio of lesions diagnosed by MSKUS.

\begin{tabular}{c|c|c|c|c|c|c}
\hline \multirow{4}{*}{} & Location & $\begin{array}{c}\text { The } \\
\text { number } \\
\text { of cases }\end{array}$ & $\begin{array}{c}\text { Slightly } \\
\text { damaged }\end{array}$ & $\begin{array}{c}\text { Moderate } \\
\text { damage }\end{array}$ & $\begin{array}{c}\text { Severe } \\
\text { damage }\end{array}$ & $\%$ \\
\hline \multirow{4}{*}{$\begin{array}{c}\text { Upper limb } \\
\text { injury }\end{array}$} & $\begin{array}{c}\text { Shoulder joint/ } \\
\text { collarbone }\end{array}$ & 4 & 3 & 0 & 1 & 11.43 \\
\cline { 2 - 8 } & Upper arm & 3 & 3 & 0 & 0 & 8.57 \\
\cline { 2 - 8 } & Hand/finger & 1 & 1 & 0 & 0 & 2.86 \\
\cline { 2 - 8 } & Wrist & 1 & 1 & 0 & 0 & 2.86 \\
\hline \multirow{3}{*}{$\begin{array}{c}\text { Lower } \\
\text { injuries }\end{array}$} & The thigh & 6 & 6 & 0 & 0 & 17.14 \\
\cline { 2 - 8 } & The knee joint & 10 & 9 & 0 & 1 & 28.57 \\
\cline { 2 - 8 } & The ankle & 6 & 6 & 0 & 0 & 17.14 \\
\hline
\end{tabular}




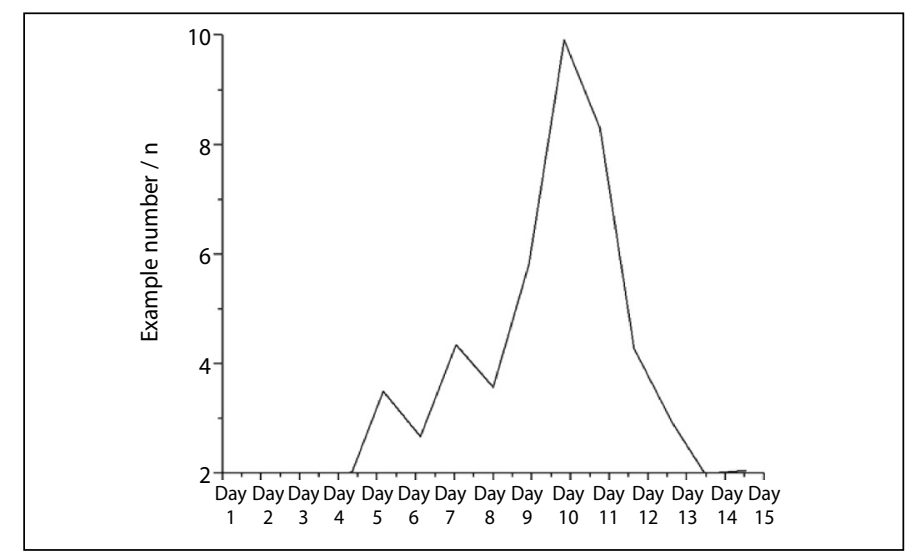

Figure 1. Daily usage of MSKUS.

definite diagnosis of MSKUS, they received timely treatment and completed the race successfully. Acute injury is a sudden injury of definite etiology. Due to the unpredictable occurrence of injury, it is necessary to judge the situation of injury earlier and more accurately in large-scale sports events. MSKUS can clearly display muscle and ligament structures, and has the advantages of high soft tissue resolution, multi-angle presentation, multi-plane display and so on. MSKUs are highly sensitive to acute minor injuries of muscles or ligaments and can be detected by the clarity of fiber echo and local enhancement or decrease of fiber echo. ${ }^{5}$ For minor injuries, MSKUS examination is usually recommended 24 to 48 hours after injury. MSKUS can be used for arthritis such as rheumatoid arthritis, synovitis and bone erosion, and is considered to be an objective and sensitive tool for rapid qualitative and quantitative assessment of arthritis, and can provide an accurate reference for the acute onset of inflammatory joint disease. ${ }^{6}$ The new technique of wide-view imaging can display the morphology and structure of bone, muscle, blood vessel, nerve and so on in the examination area. Compared with two-dimensional ultrasound, three-dimensional ultrasound has a higher detection rate for small lesions, and has a higher detection rate for local lesions such as small tendons and ligaments.?

\section{Defining the degree of chronic strain injury, auxiliary posi- tioning treatment, and reducing the psychological burden of athletes}

In this study, there were 26 athletes with chronic injury, accounting for $74.29 \%$. Chronic strain injury is one of the main factors affecting the improvement of athletes' performance. During competition, the psychological burden of chronic strain is often greater than the impact of the disease itself. MSKUS can clarify the degree of chronic strain, assist in positioning treatment, relieve chronic pain, so as to reduce the psychological burden of athletes, and ensure athletes to participate in the best state. In this study, it was found that the sites of chronic injuries mostly occurred in the shoulder joint, knee joint and plantar fascia, which was consistent with some research conclusions. MSKUS has a high sensitivity and specificity for the diagnosis of shoulder pain. Using MRI as the gold standard, the sensitivity and specificity of ultrasound diagnosis are 100\% and $87 \%$. Chronic knee pain is mostly caused by meniscus injury and excessive use of surrounding ligaments. ${ }^{8} X$-rays and $\mathrm{CT}$ can often show the fracture status more clearly, but the diagnosis of cartilage injury is less accurate. MSKUS has obvious advantages in the diagnosis of cartilage injury, such as meniscus injury, static combined with dynamic stress ultrasound can significantly improve the sensitivity and specificity of ultrasonic diagnosis of meniscus injury. ${ }^{9}$ MSKUS real-time shear wave ultrasound elastography combined with conventional ultrasound can be used to evaluate muscle/ ligament injuries. Ultrasound elastography can determine the hardness of tissue by detecting the parameters such as tissue strain, strain rate or shear wave velocity under external force or ultrasound, which can quantitatively simulate the effect of clinical "palpation". The use of elastography to measure the elasticity of muscle and tendon tissue is helpful in identifying obsolete injuries and degenerative lesions. MSKUS examination is a sensitive index for the diagnosis of plantar fasciitis. The thickness of the healthy side in normal people is usually less than $4 \mathrm{~mm}$. If the thickness is between $4 \sim 5 \mathrm{~mm}$, and there is echogenic reduction, perifascial exudation and other manifestations, it can be considered as plantar fasciitis. MSKUS can clearly display the fibrous structure and layers of the plantar fascia. Bilateral comparison is used to track the overall situation of the ligament according to the path of the ligament. ${ }^{10}$

\section{CONCLUSION}

The application value of MSKUS has been recognized through the application practice of athletes in this sports meeting. Analyzing the sports injury and following up the athletes'recovery, the real-time application value of MSKUS in sports meeting was preliminarily discussed. The results showed that tendons and ligaments were the most common sports injuries; MSKUS has certain advantages in the field real-time diagnosis of tendon, ligament and soft tissue; Combined with MSKUS can help doctors to judge the injury situation more quickly and accurately, and guide the next step of exercise prescription and rehabilitation treatment plan more effectively. MSKUS can clearly diagnose athletes' acute injuries during competition, dynamically observe the progress of chronic injuries, and provide objective basis for treatment during competition, it alleviates the anxiety caused by the uncertain diagnosis of athletes and coaches, and ensures the rapid and efficient return of athletes to the game. With the wide application of MSKUS in the field of sports medicine and the continuous development of ultrasound technology, its unique advantages will make it play a more important role in the assessment of normal muscle function and the early warning of sports injury.

All authors declare no potential conflict of interest related to this article

AUTHORS' CONTRIBUTIONS: Each author made significant individual contributions to this manuscript. Qingwen Tan: writing and performing surgeries; Seung-Soo Baek: data analysis and performing surgeries, article review and intellectual concept of the article.

\section{REFERENCES}

1. Henriques-Neto D, Magalhães JP, Hetherington-Rauth M, Santos DA, Baptista F, Sardinha LB. Physical Fitness and Bone Health in Young Athletes and Nonathletes. Sports Health. 2020;12(5):441-8. doi: 10.1177/1941738120931755.

2. Baranello G, Vai S, Broggi F, Masson R, Arnoldi MT, Zanin R, et al Evolution of bone mineral density, bone metabolism and fragility fractures in Spinal Muscular Atrophy (SMA) types 2 and 3. Neuromuscul Disord. 2019;29(7):525-32. doi: 10.1016/j.nmd.2019.06.001.

3. Payushina OV, Domaratskaya El, Sheveleva ON. Participation of mesenchymal stromal cells in muscle tissue regeneration. Biology Bulletin Reviews. 2019;9(5):393-402. doi: 10.1134/S2079086419050062.

4. Ramirez E, Khartabil A, Marin Y, Escalante G. relationships of bone mineral density and muscular performance in college students. Medicine \& Science in Sports \& Exercise. 2020;52(7S):69-69.

5. Di Zanni E, Gradogna A, Picco C, Scholz-Starke J, Boccaccio A. TMEM16E/ANO5 mutations related to bone dysplasia or muscular dystrophy cause opposite effects on lipid scrambling. Hum Mutat. 2020;41(6):1157-1170. doi: 10.1002/humu.24006.

6. Zhang LL, Liu B, Sun FF, Li HY, Li S, Zhao LR. Papillary thyroid carcinoma with hyperthyroidism and multiple metastases: A case report. Medicine (Baltimore). 2020;99(30):e21346. doi: 10.1097/ MD.0000000000021346.

7. Gao X, Tang Y, Amra S, Sun X, Cui Y, Cheng H, et al. Systemic investigation of bone and muscle abnormalities in dystrophin/utrophin double knockout mice during postnatal development and the mechanisms. Hum Mol Genet. 2019;28(10):1738-51. doi: 10.1093/hmg/ddz012.

8. Hemke R, Buckless CG, Tsao A, Wang B, Torriani M. Deep learning for automated segmentation of pelvic muscles, fat, and bone from CT studies for body composition assessment. Skeletal Radiol. 2020;49(3):387-95. doi: 10.1007/s00256-019-03289-8.

9. Kovalko NY, Kalinina MV, Suslov DN, Galibin OV. Effect of t-ZrO2-Based Ceramic Samples on the Condition of Muscular and Connecting Tissues in Experimental Animals with Intramuscular Introduction. Inorganic Materials: Applied Research. 2019;10(5):1109-14. doi: 10.1134/S2075113319050149.

10. Zheng WB, Dai Y, Hu J, Zhao DC, Wang O, Jiang Y, et al. Effects of bisphosphonates on osteoporosis induced by Duchenne muscular dystrophy: a prospective study. Endocr Pract. 2020;26(12):1477-85 doi: 10.4158/EP-2020-0073. 